\title{
Clinical and laboratorial evidence of Rickettsia felis infections in Latin America
}

\author{
Evidência clínica e laboratorial de infecções \\ por Rickettsia felis na América Latina
}

\author{
Márcio Antônio Moreira Galvão ${ }^{1}$, Cláudio Mafra ${ }^{2}$, Chequer Buffe Chamone ${ }^{3}$, \\ Simone Berger Calic ${ }^{3}$, Jorge E. Zavala-Velazquez ${ }^{4}$ \\ and David Hughes Walker ${ }^{5}$
}

\begin{abstract}
After the discovery and initial characterization of Rickettsia felis in 1992 by Azad and cols, and the subsequent first description of a human case of infection in 1994, there have been two communications of human rickettsiosis cases caused by Rickettsia felis in Latin America. The first one was published in 2000 by Zavala-Velazquez and cols in Mexico. In 2001 Raoult and cols described the occurrence of two human cases of Rickettsia felis rickettsiosis in Brazil. In the present discussion these two articles were compared and after the description of the principal signs and symptoms, it was concluded that more studies are needed with descriptions of a greater number of patients to establish the true frequency of the clinical signs and symptoms present in Rickettsia felis rickettsiosis.
\end{abstract}

Key-words: Rickettsia felis. Rickettsioses. Latin America.

\section{RESUMO}

Depois da descoberta e caracterização inicial da Rickettsia felis em 1992 por Azad e cols, e à descrição subseqüente do primeiro caso de infecção humana em 1994, houveram duas comunicações de rickettsioses causadas por Rickettsia felis na América Latina. Aprimeira foi feita por Zavala-Velazquez e cols em 2000 no México. Em 2001, Raoult e cols descreveram a ocorrência de dois casos humanos de rickettsiose por Rickettsia felis no Brasil. Na presente discussão, esses dois artigos foram comparados, e depois da descrição dos principais sinais e sintomas, conclui-se que outros estudos são necessários, com a participação de um maior número de pacientes, para se estabelecer a verdadeira frequêencia dos sinais clínicos e sintomas presentes nas rickettsioses por Rickettsia felis.

Palavras-chaves: Rickettsia felis. Rickettsioses. Latin America.

The pathogenic rickettsiae are a group of intracellular bacteria responsible for a variety of human diseases. Rickettsia rickettsii and Rickettsia typhi and their respective diseases, Brazilian spotted fever, the equivalent of Rocky Mountain spotted fever transmitted by the Amblyomma cajennense tick, and murine typhus transmitted by the Oriental rat flea, have been known in Brazil since the $1920 \mathrm{~s}^{56}$.

Rocky Mountain spotted fever was documented in Mexico during the 1930s, although epidemic typhus caused by
Rickettsia prowazekii had importance in the outbreaks that have been described since 1736. Rickettsial diseases have subsequently received little attention in tropical areas of Latin America. Endemic Rocky Mountain spotted fever and other rickettsioses such as epidemic typhus have been identified in countries of Latin America only because their high fatalitycase ratio has demanded investigation. It is possible that other spotted fever group rickettsioses have occurred unrecognized in Mexico and Brazil for long periods.

\footnotetext{
1. Departamento de Nutrição Clínica e Social da Escola de Nutrição da Universidade Federal de Ouro Preto, Ouro Preto. MG. 2. Departamento de Bioquímica e Biologia Molecular da Universidade Federal de Viçosa, Viçosa, MG. 3. Fundação Ezequiel Dias, Belo Horizonte, MG. 4. Universidad Autônoma de Yucatán, Mexico. 5. World Health Organization Collaborating Center for Tropical Diseases of University of Texas Medical Branch, Texas, USA. Address to: Dr. Márcio A. Moreira Galvão. DNCS/EN/UFOP, 35400-000 Ouro Preto, MG, Brazil.

Tel: 55 313559-1838.

e-mail: mgalvao@ enut.ufop.br.

Recebido para publicação em 20/11/2002

Aceito em 23/4/2004
} 
Serological and clinical evidence of severe and mild-tomoderate cases of rickettsioses and the application of molecular methods including detection by PCR amplification and characterization by DNA sequence analysis has allowed the identification of new species of Rickettsia, such as R. felis in opossums, fleas ${ }^{1910}$ and blood and skin from diseased humans in the USA, Mexico, France, Brazil, and Germany ${ }^{2}{ }^{2811}$.

\section{MATERIAL AND METHODS}

During the 1990's reports of serological studies in Mexico ${ }^{12}$ and Brazil ${ }^{3}$ discussed the possibility of the existence of other rickettsioses in these countries. In the role of the new rickettsioses, $R$ felis rickettsiosis currently appears to be one of the mostimportant. Some authors ${ }^{711}$ have discussed the existence of human cases caused by this bacterium in Mexico and Brazil. The objective of this article was to compare the data and clinical symptoms of human rickettsiosis cases described in these two communications and to evaluate the severity, epidemiology and clinical course of this new rickettsiosis.

\section{RESULTS}

In Mexico three patients with fever, exanthem, headache and central nervous system involvement were diagnosed with R. felis infection by specific PCR of blood in two cases and PCR of skin in another case. In all three cases, acute serum samples contained no detectable antibodies to rickettsiae. The convalescent sera contained antibodies at a titer of 1:64 to Rickettsia akari, R. rickettsii and R. typhi ${ }^{11}$.

PCR amplification of DNA from skin biopsy and blood samples with specific primers for the Rickettsia $17 \mathrm{kDa}$ protein gene was confirmed by DNA sequencing, which showed that the sequence was $100 \%$ identical to $\mathrm{R}$. felis ${ }^{11}$. In the two human cases of $\mathrm{R}$. felis rickettsiosis in Brazil, first suspected to be Brazilian spotted fever, the disease was confirmed in serum by IFA ( IgG/IgM) with high titers to R. felis (1024/64 and 512/64) and by identification of
R. felis in one case by DNA sequencing following nested-PCR amplification from a serum sample ${ }^{8}$.

In both reports from Mexico and Brazil (Figure 1), the patients ( five) initially had systemic symptoms (fever, headache and myalgia). All the cases also showed a rash. Visceral involvement was suggested in all patients with abdominal pain, nausea and vomiting and diarrhea in four patients. Four patients had involvement of central nervous system with photophobia in two patients from Mexico and hearing loss and signs of meningismus in the other one and the presence of coma in one of the Brazilian cases. One patient from Mexico had conjunctivitis. Laboratory data in the Brazilian cases revealed thrombocytopenia (platelets $<100,000 / \mathrm{mm}^{3}$ ) and increased serum concentration of aspartate transaminase associated with hepatosplenomegaly. One of the three Mexican cases manifested anemia, leukocytosis, thrombocytosis and prolonged prothrombin time. The third one showed leukopenia.

\section{DISCUSSION}

The clinical manifestations in these patients increase our knowledge of the illness caused by $\mathrm{R}$. felis infection.

Fever, headache, and myalgia suggested systemic acutephase response, the exanthem reflects a vasculitis, a common manifestation of rickettsial diseases, and the occurrence of abdominal pain, nausea, vomiting and diarrhea indicate possible visceral involvement. Neurological symptoms suggest that we are facing a potentially severe new rickettsial disease.

The epidemiologic data suggested contact with an opossum in one of the Mexican cases, and with fleas and ticks in the Brazilian patients and one of the Mexican cases. Regarding treatment, the Brazilian cases received chloramphenicol, and in the Mexican cases one patient received doxycycline after the acute illness. All these cases survived in the two countries studied.

More studies are needed to establish the real frequency of the symptoms present in R. felis rickettsiosis, the true casefatality ratio of this disease, the epidemiology and the role of R. felis as an important pathogen.

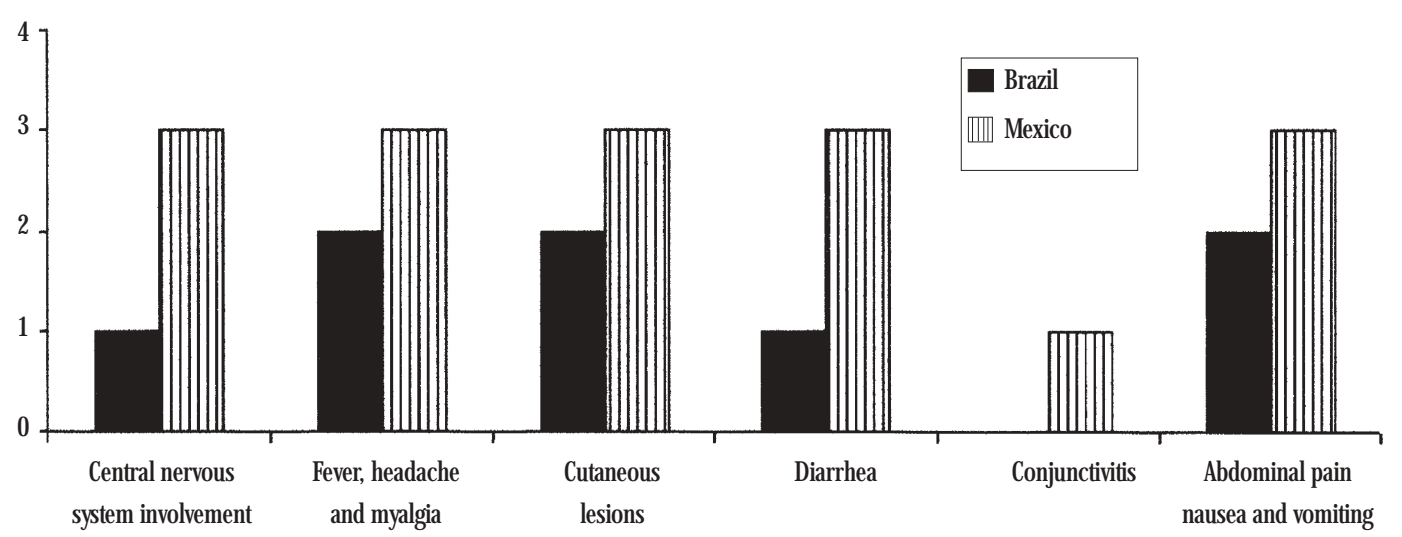

Clinical signs and symptoms

Figure 1 - Clinical and symptoms in Brazilian and Mexican patients with Rickettsia felis infection. 


\section{REFERENCES}

1. Azad AF, Sacci Jr JB, Nelson WM, Dasch GA, Schmidtmann ET, Carl M. Genetic characterization and transovarial transmission of a typhus-like Rickettsia found in cat fleas. Proceedings of National Academy of Science of the United States of America 89:43-46, 1992.

2. Bouyer DH, Stenos J, Croquet-Valdes P, Moron CG, Popov VL, ZavalaVelazquez JE, Foil LD, Stothard DR, Azad AF, Walker DH. Rickettsia felis: molecular characterization of a new member of the spotted fever group. International Journal of Systematic and Evolutionary Epidemiology 51:339347, 2001.

3. Galvão MAM, Chamone, CB, Calic SB, Machado MC, Otoni MEA, Dietze R, Moron C, Feng HM, Olano JP, Walker DH . Serologic evidence of spotted fever group Rickettsia in Novo Cruzeiro Municipality-Minas Gerais StateBrazil. In: Raoult D, Brouqui P (eds) Rickettsial Diseases at the Turn of the Third Millennium, Marseille, Elsevier p. 240-243, 1999.

4. Higgins JA, Sacci JB, Schriefer ME, Endris RG, Azad AF. Molecular identification of Rickettsia-like microorganisms associated with colonized cat fleas (Ctenocephalides felis). Insect Molecular Biology 3:27-33, 1994.

5. Monteiro JL, Fonseca F. Typho endêmico de São Paulo. Novas experiências sobre a transmissão experimental por carrapatos Boophilus microplus e
Amblyomma cajennense. Memórias do Instituto Butantan (São Paulo) 10:33-50, 1932.

6. Piza JT. Considerações epidemiológicas e clínicas sobre o Tifo Exantemático de São Paulo. São Paulo, Sociedade Impressora Paulista 11-119, 1932.

7. RaoultD, Fournier P-E, Abboud P, Caron F. First documented human Rickettsia aeschlimannii infection. Emerging Infectious Diseases 8:748-749, 2002.

8. Raoult D, La Scola B, Enea M, Fournier P-E, Roux V, Fenollar F, Galvão MAM, Lamballerie X. A flea associated Rickettsia pathogenic for humans. Emerging Infectious Diseases 7:73-81, 2001.

9. Schriefer ME, Sacci JB Jr, Dumler JS, Bullen MG, Azad AF. Identification of a novel rickettsial infection in a patient diagnosed with murine typhus. Journal of Clinical Microbiology 32:949-954, 1994.

10. Schriefer ME, Sacci Jr JB, Taylor JP, Higgins JA, Azad AF. Murine typhus: updated roles of multiple urban components and a second typhus-like Rickettsia. Journal of Medical Entomology 31:681-685, 1990.

11. Zavala-Velazquez JE, Ruiz-Sosa JA, Sanchez-Elias RA, Becerra-Carmona G, Walker DH. Rickettsia felis rickettsiosis in Yucatan. Lancet 356:10791080, 2000.

12. Zavala-Velazquez JE, Yu XJ, Walker DH. Unrecognized spotted fever group rickettsioses masquerading as dengue fever in Mexico. American Journal of Tropical Medicine and Hygiene 55:157-159, 1996. 